\title{
Distance Learning Training with Google Classrom at SMAN 1 Sibabangun Regency Central Tapanuli
}

\author{
JHONAS DONGORAN ${ }^{1}$,BRONIKA SEPTIANI ${ }^{2}$, ,ULMAWATI $^{3}$ \\ ${ }^{1}$ STKIP Riama Biology Education \\ ${ }^{2}$ STKIP Riama Chemistry Education \\ ${ }^{3}$ STKIP Riama Civic Education \\ Email : dongoran231089@gmail.com
}

Received 20 June 2021 | Revised 27 June 2021 | Accepted 28 June 2021

\begin{abstract}
In distance learning, the role of technology is needed to be able to connect with one another. One of the learning media that can be used for distance learning is Google Classroom. Mastery of technology and information for teachers at SMAN 1 Sibabangun, Central Tapanuli Regency is very necessary in this distance learning. The effort that must be made by a teacher in providing distance learning is to create media such as Google Classroom. Through Google Classroom, teachers can create classes for teaching and learning activities and students can take classes. In this training, teachers can give assignments, provide assessments of student assignments, import learning materials, and also make quizzes for students. The result of the service carried out is that the teacher is able to make learning media using google classroom so that distance learning can run more effectively. With the dedication that is carried out, it can realize the vision and mission of the SMAN 1 Sibabangun school, Central Tapanuli Regency. The results of the questionnaire from this community service activity are very good at $42.94 \%$, good at $48.89 \%$, enough at $7.6 \%$, less at $0.55 \%$, and very poor at $0.01 \%$.
\end{abstract}

Keywords: Learning Media, Training, Google Classroom

\section{INTRODUCTION}

In the province of North Sumatra, especially Central Tapanuli Regency, face-to-face learning activities were stopped. Teachers choose to carry out learning activities using online learning. In accordance with the circular letter of the Head of the Education Office of North Sumatra Province Number 420/2969/Subbag Umum/IV/2020, the Government of North Sumatra is responsible for the implementation of formal education activities at the SMA and SMK levels regarding the Extension of Distance/Online Learning Implementation on April 02, 2020, decided to extend the learning period of students at home. In this way, teaching and learning activities that were originally carried out at school become learning from home. Online learning is not as simple as imagined, because it requires the readiness of all parties involved in it starting from schools, teachers, students, parents students, telecommunication devices, online teaching materials, and so on. Teachers must be able to choose the right learning method so that the learning objectives that have been designed can be achieved. 
Learning in a network where the teacher and students/students do not meet face-to-face in class requires the ability to determine effective learning methods.

Seeing the reality that is happening today where environmental conditions force the distance learning process. We agree that all teachers must be able to teach remotely which of course must use technology. The ability that must be possessed by teachers to be able to carry out distance learning in addition to mastering pedagogic competence and professional competence must also master and utilize communication technology in learning. Moreover, the ability of teachers to use distance learning applications is absolutely necessary. At least the teacher has one ability to use and create online teaching materials. Teachers must also be able to prepare learning systems, syllabus and learning methods with digital or online learning patterns.

Besides that, teachers must also understand that online learning patterns are part of all learning although only as a complement not only during the learning period at home as it is today but also for normal circumstances. Teachers should be ready with all situations so that they can continue to do learning with their students by mastering online learning technology and various suitable online learning methods. For this reason, teachers with their own awareness should continue to learn, including improving online learning skills without having to wait for an online learning training program from the government (Syahdian, 2021).

Distance learning activities are not easy to apply to teachers because one of them is the uneven ability or competence of teachers in managing distance learning (Azzahra, 2020). Distance learning is indeed a new category in learning in secondary schools, so there are obstacles in its implementation in the field. This distance learning system is also not maximally implemented in schools. The involvement of the parent community and school committee is also needed to ensure the continuity of quality learning for students. Parental involvement in children's learning is very important. However, so that mentoring for children has benefits, parents are expected to be able to: strengthen their spiritual footing to the Creator, uphold love, give appreciation to children, provide a safe, healthy, and friendly environment and be exemplary parents (Suhendri, 2021). If this is done consistently by parents in the family environment, it will not only benefit the child and the phases and learning processes he goes through, but will also result in overall family resilience.

The purpose of this service is to provide knowledge and training for participants in using the classroom to facilitate learning activities. The methods used in the implementation of this service are lectures, questions and answers, discussions and demonstrations (Malalina, 2018). The training using e-learning Classroom includes 3 stages, namely: 1) the preparation stage, digging into problems regarding e-learning by presenting the material, 2) the implementation stage, training in using the Classroom, and 3) the evaluation stage, the obstacles that exist during the training (Novian, 2019). Classroom is a web-based learning tool from Google. There were several problems found related to google classroom-based learning: namely: a) teachers did not have the knowledge and skills to design learning based on google classroom, b) teachers did not know the concept of web-based learning, c) teachers did not understand how to create classes based on google classroom and do not know how to manage classes based on google classroom, d) The absence of human resources who master the concept of learning based on google classroom and its application (Muhiddin Palennari, 2019).

Activities from this service can make it easier for teachers to convey material and provide questions for assignments from the classroom media and can create classes for students according to the subjects taken, so that e-learning learning can run in online classes. The 
use of the Google Classroom-based E-learning application as a medium in learning makes it easier for teachers to archive and organize assignment files and the assessment process (Mu'minah, 2020). The use of Google classroom is very flexible, easy to access anywhere and anytime, constrained internet access from the absence of a data network or smartphone that is used to support all students for the implementation of e-learning learning (Rini Atikah, 2021). At this time, namely the Covid-19 virus epidemic, forcing humans to change interactions between humans in reducing the impact of the spread of this virus. One of them is doing social distancing where everyone has to manage social distance. Face-to-face activities that are usually carried out can no longer be carried out so they are replaced by conducting online or online learning. Online learning activities can use learning media such as Google Classroom which can help maximize teacher teaching activities and student learning (Alexander F.K. Sibero, 2020). Activities in training using classroom tools have the goal of introducing the functions and benefits of the tool to students. The advantages of blended learning are that it combines online and face-to-face learning methods, so that it can create comfort for students and activity in the classroom (Wicaksono, 2017). A qualitative approach is the method used in this service. Participants in the training can create content related to education and upload it on YouTube (Ahmad Chusyairi, 2021).

The community implementation team from STKIP Riama focuses on providing training with the target of teachers in increasing knowledge and skills in online learning. In this service, a qualitative approach is carried out. From the explanation above, in order to achieve the vision and mission of SMAN 1 Sibabangun, it is necessary to provide training to teachers of SMAN 1 Sibabangun to achieve the vision and mission of the Education Office.

\section{MATERIALS AND METHOD}

In this community service implementation activity, it is carried out face-to-face with one person as a resource person, one person as a Moderator and two persons as technical supporters and the number of participants is thirty teachers of SMAN 1 Sibabangun. The implementation of this service activity was carried out on April 12, 2021, which took place at SMAN 1 Sibabangun, Central Tapanuli Regency using the training method for making learning media with materials that contained: giving assignments, giving student assessments, inputting learning materials, and also making quizzes for students. The evaluation carried out on this service was in the form of filling out a questionnaire by the training participants as feedback on community service using five assessments criteria, namely: Very Good, Good, Enough, Less, and Very Poor.

\section{RESULT AND DISCUSSION}

The implementation of community service focuses on finding solutions in managing learning during this pandemic. The activity in carrying out the Distance Learning Media Making Training during this pandemic is a new activity using Google Classroom for teachers at SMAN 1 Sibabangun. The materials provided in this service are:

\section{a) Module 1 (making a class)}

The following steps: open classroom.google.com. On the class page click add $(+)$ then select create class. Enter the class name. Then put a check mark $(\sqrt{ })$ on the message: I have read and understand the notice above, and I am not using Classroom at school with students and select the Continue button. After that, enterbrief description, grade level, or class schedule, click Section and enter details. Then to add a subject, click 
Subject, then enter a name or select a name from the list that appears when entering text. After that to enter the location of the class, select the Room and enter the details. Thenselect Create button. Classroom will then automatically generate a class code that can be used forinvite students to class. Teachers can get the class code at the top of the class forum at any time. In activating the class provided so that it can be seen by students, first login first then on the class card select accept. After that confirmeven students and class activation, then click Accept. To change the theme onGoogle Classroom by selecting a theme in the gallery window, select a theme by placing a check mark () then selecting the Select class theme button. For galleries containing: general, english \& history, math \& science, arts, sports, and other. The result of changing the theme in Google Classroom based on the theme that has been selected by the user

\section{b) Module 2 (Creating learning topics)}

The following steps : create a new task select class then Class assignments. At the top select create topic then enter the name of the topic and select add.In creating a new material or topic, click Assignment then Create then Material, after that enter: title, description in the form of a short description of the subject, and add material that is connected to Google Drive media (select file then select Add button), Link (enter URL link then click Add Link), File (drag and drop a file or select a file on your computer and then select the Upload button) and YouTube (enter keywords in the search by pressing the search button, if you find the video you want to search for then select Add). Choose a topic as needed. Post to publish the material select the post button then schedule. To edit the learning topic by selecting the edit material button on the topic, in the description (optional) add, select the schedule button. Upload a slide then select edit topic material, then add a clip icon at the bottom left, a dialog box will appear on Google Drive then Insert file with Google Drive, so you can add material by using Drag File here or select file from device then click Upload, click Schedule, as well as the results of material uploads. Upload a topic or video material on YouTube, click edit, then click add clip icon at the bottom left, then click the YouTube icon button until a dialog box appears. Insert video then adjust the video search you want or you can by typing keywords in the search in the video search then clicking the search button, the output will appear based on the keywords entered in the video search. In addition to that method, it can also be done by copying links related to search keywords in the URL. If the video is in accordance with the desired then click add. Then click the save button to save the video connected to YouTube. Add material or topics to the link by selecting edit material on the topic then clicking the add menu with the clip icon on the bottom left. Select the Link icon, it will display the Add Link dialog box

\section{c) Module 3 (How to invite students by distributing class codes to students)}

The following steps : Select the forum in the header section under the class title, there is a class code consisting of 6 or 7 alphanumeric digits then invite students. First, login with a Google account where students first enter the Google Classroom application and then click the advanced menu. Select the plus sign (+) at the top right, then select join class. Enter the class code that has been given by the teacher (SMAN 1 Sibabangun teacher) then select join. If successful, the main class page for students will appear. On the main page of the teacher or teacher will appear students in the member menu. Then invite the students of SMAN 1 Sibabangun by using e-mail. Then select members at the far right of the select invite students section then the Invite students dialog box appears. In the Invite students dialog box, type the student's name or e-mail. Then click invite to finish. In the teacher or teacher view, the addition of students who have been invited via email will appear. If an error is found when inviting by e-mail, then put a 
check mark $(\sqrt{ })$ in the invited student's email, then click Action then Remove. Show notification Expel student? in the form of a question Are you sure you want to remove this student from class? If you are sure, then select the Eject button and if you are not sure, then click the Cancel button. Students who use a Google account and then log in will receive an e-mail invitation from the teacher to join the class on Google Classroom. When pressing the join button, a notification display will appear in the form of a join class to join the class being held then click join and select Continue to continue joining the class

\section{d) Module 4 (Interaction between Teachers and Students)}

The following steps : The sender of an email to a student by selecting a student member, to the right of the student's name and then clicking Send email to students. Write the subject of the email, the contents of the e-mail and end by selecting the send button. Email from the teacher will be sent to the email address of the intended student. Send an email to a student by selecting a member on the student then checklist $(\sqrt{ })$ on the desired student on the Action click Send email, write the subject and content of the email from the teacher or teacher to the student (student), and end by pressing the Send button, so that e-mail mail from the teacher can be sent to the address of the student to be addressed. Interaction with class comments, students can comment or ask the teacher in a post in the Forum or Classwork section. For students, click on one of the materials in the forum, then click on the material. Select the class comment at the bottom then type a comment and end by selecting a post. For the teacher's view on the Forms menu, 1 class comment will appear in the material post. The teacher or teacher can reply to comments in class by sending a message in the position below the Student's comment then click Post to send the message

e) Module 5 (Making Assessment that consisting of: title, instructions (optional), to, point , deadlines, topics, and add (Google Drive, Links, Files and YouTube)) The following steps : create documents in word form, slides in the form of presentation slides, spreadsheets in excel form, images in the form of drawings and forms in the form of forms. Assignments that have been uploaded will find the status: students can view files, students can edit files, and make a copy for each student. Students complete assignments in the Assignment List, then select the Add or Create menus (Google Drive, Links, Files) and Create New (Documents, Slides, Sheets, and Drawings). The teacher evaluates the results of student assignments using student work examinations, giving statements, giving grades and returning the results of the evaluation (select Return) to students. For student positions, the evaluation that has been submitted by the teacher can be seen and if allowed the teacher can send it back to improve the score. If the answer is in accordance with the task given by the teacher, then the value given to the student can be changed by the teacher accompanied by comments posted for the assignment. The value that has been updated by the teacher through the student Resend results will appear automatically from the student side. 
Questionnaire for participants as feedback in which there were 30 teachers of SMAN 1 Sibabangun which consisted of 10 questions and can be seen in the following table:

Table 1. Percentage of Feedback Questionnaire Rating

\begin{tabular}{|c|c|c|c|c|c|c|}
\hline \multirow[t]{2}{*}{ No. } & \multirow[t]{2}{*}{ Question } & \multicolumn{5}{|c|}{ Category Distribution Value(\%) } \\
\hline & & $\begin{array}{l}\text { Very } \\
\text { Poor }\end{array}$ & Less & Enough & Good & $\begin{array}{l}\text { Very } \\
\text { good }\end{array}$ \\
\hline 1 & $\begin{array}{l}\text { Presentation of material } \\
\text { by the resource person }\end{array}$ & $0 \%$ & $0 \%$ & $6.67 \%$ & $56.67 \%$ & $36.67 \%$ \\
\hline 2 & $\begin{array}{l}\text { The response of the } \\
\text { training participants to } \\
\text { the material presented }\end{array}$ & $0 \%$ & $0 \%$ & $6.67 \%$ & $40 \%$ & $53.33 \%$ \\
\hline 3 & $\begin{array}{l}\text { The relationship between } \\
\text { the material or topics } \\
\text { presented and the needs } \\
\text { of the trainees }\end{array}$ & $0 \%$ & $0 \%$ & $6.67 \%$ & $36.67 \%$ & $56.67 \%$ \\
\hline 4 & $\begin{array}{l}\text { The relationship between } \\
\text { the material and the } \\
\text { application absorbed by } \\
\text { the training participants }\end{array}$ & $0 \%$ & $0 \%$ & $6.67 \%$ & $53.33 \%$ & $40 \%$ \\
\hline 5 & $\begin{array}{l}\text { The relationship between } \\
\text { material and needs }\end{array}$ & $0 \%$ & $0 \%$ & $6.67 \%$ & $36.67 \%$ & $56.67 \%$ \\
\hline 6 & Presentation technique & $0 \%$ & $0 \%$ & $10 \%$ & $43.33 \%$ & $46.67 \%$ \\
\hline 7 & $\begin{array}{l}\text { Time spent in delivering } \\
\text { materials }\end{array}$ & $0 \%$ & $0 \%$ & $10 \%$ & $43.33 \%$ & $46.67 \%$ \\
\hline 8 & Material Clarity & $0 \%$ & $3 \%$ & $6.67 \%$ & $50 \%$ & $40 \%$ \\
\hline 9 & $\begin{array}{l}\text { Interest of the training } \\
\text { participants in the } \\
\text { activities }\end{array}$ & $0 \%$ & $0 \%$ & $6.67 \%$ & $46.67 \%$ & $43.33 \%$ \\
\hline 10 & Overall satisfaction level & $0 \%$ & $0 \%$ & $6.67 \%$ & $36.67 \%$ & $56.67 \%$ \\
\hline
\end{tabular}

The results of the feedback questionnaire in Community Service are very good at $42.94 \%$, good at $48.89 \%$, enough at $7.6 \%$, less at $0.55 \%$, and very poor at $0.01 \%$. It is necessary to evaluate the implementation of community service in order to further improve the materials or modules that will be given to the training participants so that they can be adapted to the needs of the service partners and also in the delivery of material to the follow-up participants of the service in order to assist in solving problems from imagery service that.

\section{CONCLUSIONS}

The conclusions in this training are:

1. Teachers are able to create media that will be used in the learning process using support from Google Classroom, so that they are able to provide distance learning information that is easily conveyed by the teacher to students so that it is of higher quality.

2. This Community Service has a module consisting of 5 modules, namely: module 1 which contains the Making of New Classes, module 2 contains the Preparation of Learning Materials, module 3 contains Invitations for Students, module 4 contains the Interaction of Teachers and Students, and module 5 contains about the Creation and Assessment of Assignments. 
3. The results of the feedback questionnaire in Community Service are:

\begin{tabular}{|l|l|}
\hline \multicolumn{1}{|c|}{ Category } & \multicolumn{1}{c|}{ Percentage } \\
\hline Very good & $42.94 \%$ \\
\hline Good & $48.89 \%$ \\
\hline Enough & $7.6 \%$ \\
\hline Less & $0.55 \%$ \\
\hline Very Poor & $0.01 \%$ \\
\hline
\end{tabular}

Suggestions for further community service are holding training on other tools in making distance learning media, in order to make it easier for teachers and students of SMAN 1 Sibabangun in online learning activities.

\section{LIST OF REFERENCES}

Ahmad Chusyairi, D. S. (2021). Pelatihan Pembuatan Media Pembelajaran Jarak Jauh Dengan Google Classroom Di SMAN 15 KOTA BEKASI. Jurnal Pengabdian Kepada Masyarakat, 44-50.

Alexander F.K. Sibero, I. H. (2020). Pelatihan Penggunaan Google Classroom Sebagai Media Pembelajaran dan Evaluasi Guru di SMK Negeri 11 Medan. Jurnal Abdimas Mutiara, 1(2), 107-114.

Azzahra, N. F. (2020). Ringkasan Kebijakan: Mengkaji Hambatan Pembelajaran Jarak Jauh di Indonesia di Masa Pandemi Covid-19.

Malalina, R. F. (2018). Pelatihan Google Classroom Untuk Mengoptimalisasi Proses Pembelajaran di FKIP Universitas Tamansiswa Palembang. Jurnal Cemerlang: Pengabdian pada Masyarakat, 1(1), 58-70.

Mu'minah, I. H. (2020). Pemanfaatan E-Learning Berbasis Google Classroom Sebagai Media Pembelajaran Biologi. Prosiding Seminar Nasional Pendidikan.

Muhiddin Palennari, F. D. (2019). Pengembangan Strategi Blended-Learning Pada Perkuliahan Biologi Dasar. Indonesia Journal of Educational Studies, 16-22.

Novian, D. R. (2019). Optimalisasi Penggunaan Google Classroom sebagai Media E-Learning bagi Mahasiswa Kedokteran Hewan Universitas Nusa 50 Cendana. Jurnal Pengabdian Kepada Masyarakat Membangun Negeri, 3(2), 7-12.

Rini Atikah, R. T. (2021). Pemanfaatan Google Classroom Sebagai Media Pembelajaran Di Masa Pandemi Covid-19. Jurnal Pendidikan Teknologi Informasi dan Komunikasi, 718.

Suhendri Suhendri, R. S. (2021). Pelatihan Pembelajaran Jarak Jauh (PJJ) Pada Masa Pandemi Covid-19 Bagi Guru Sekolah Dasar Islam Terpadu (SDIT) DOD Medan. Jurnal Pengabdian Kepada Masyarakat, 1-5.

Syahdian. (2021, April 5). Kesiapan Pembelajaran Metode Berbasis Proyek Dalam Jaringan (DARING) Antisipasi COVID-19. Diambil kembali dari Ipmp-sumut.kemdikbud.go.id: https://lpmp-sumut.kemdikbud.go.id/kesiapan-pembelajaran-metode-berbasisproyek-dalam-jaringan-daring-antisipasi-covid-19-2/

Wicaksono, V. D. (2017). Pembelajaran Blended Learning Melalui Google Classroom Di Sekolah Dasar. Seminar Nasional Pendidikan PGSD UMS \& HDPGSDI Wilayah Jawa. Solo. 